\title{
APLIKASI PENGINDERAAN JAUH UNTUK ANALISIS PENGARUH RUANG TERBUKA HIJAU TERHADAP IKLIM MIKRO DI KAWASAN PERKOTAAN KLATEN
}

\section{Eni Susanti ${ }^{1}$ dan Iswari Nur Hidayati ${ }^{2}$}

Fakultas Geografi, Universitas Gadjah Mada, Yogyakarta, Indonesia,

enisusann@gmail.com

Diterima : Februari 2015 ; Direvisi : Maret 2015.; Dipubikasikan: 30 September 2015

\begin{abstract}
ABSTRAK Keberadaan RTH Hijau mulai tergusur oleh adanya pembangunan bangunan-bangunan baru di kawasan perkotaan. Salah satu fungsi dari RTH adalah sebagai pengatur dan penyeimbang iklim mikro. Citra ALOS Pan-Sharpened digunakan untuk interpretasi RTH dan penggunaan lahan. Hasil akhir penelitian ini adalah peta distribusi suhu udara, kelembaban relatif, dan kecepatan angin di kawasan perkotaan Klaten, tingkat hubungan antara kerapatan RTH terhadap iklim mikro, pola RTH terhadap iklim mikro, dan penggunaan lahan terhadap iklim mikro. Hasil penelitian menunjukkan bahwa citra ALOS Pan-Sharpened memberikan ketelitian interpretasi kerapatan RTH sebesar 81,05\%, untuk interpretasi pola RTH sebesar 93,68\%, dan interpretasi penggunaan lahan sebesar $94,97 \%$. Kerapatan RTH berpengaruh terhadap suhu udara $60,6 \%$, kelembaban udara $80 \%$, kecepatan angin 5,2\%. Pola vegetasi RTH kurang memberikan pengaruh yang signifikan terhadap iklim mikro. Pengaruh penggunaan lahan terhadap iklim mikro adalah rendah, dimana lebih dipengaruhi oleh ketersediaan RTH , tingkat kepadatan bangunan, geometri bangunan, dan emisi gas kendaraan bermotor.
\end{abstract}

Kata kunci: Citra ALOS Pan-Sharpened; iklim mikro; ruang terbuka hijau (RTH).

\begin{abstract}
The presence of Open Green Space is threatened by conversion to new buildings in urban areas. One of the function of Open Green Space is as a regulator and balancing of micro climate. ALOS Pan-Sharpened images was used to Open Green Space and land use interpretation. The final result of this research is a distribution map of air temperature, relative humidity, and wind speed in Klaten's urban areas, relations level between Open Green Space density to the micro climate, Open Green Space pattern to the micro climate, and land use to the micro climate. The result of this research showed that interpretation accuracy of Open Green Space density provided by ALOS Pan-Sharpened was $81,05 \%$, interpretation of Open Green Space pattern was 93,68\%, and interpretation of land use was $94,97 \%$. On the other hand, Open Green Space density affect to the air temperature was $60,6 \%$, to the air humidity was $80 \%$, and to the wind speed was 5,2\%. Vegetation patterns of Open Green Space gave less significant influence to the micro climate which marked by very weak correlation between many vegetation patterns of Open Green Space with air temperature, air humidity, and wind speed. Land use impact to the micro climate were low, where air temperature, air humidity, and wind speed were more influenced by buildings density level, building geometry, gas emissions from vehicles, and Open Green Space availability.
\end{abstract}

Key words: ALOS Pan-Sharpened images; micro climate; open green space.

\section{PENDAHULUAN}

Kawasan perkotaan Klaten memiliki luasan lahan terbangun yang terus meningkat setiap tahun. Perkembangan kota yang terus meningkat berdampak pada penurunan jumlah RTH yang akhirnya menyebabkan penurunan kualitas lingkungan. Padahal kenyatannya RTH sangat diperlukan dalam menyeimbangkan dan mengendalikan iklim mikro di kawasan perkotaan.

Material permukaan yang didominasi oleh lahan terbangun akan mempunyai pengaruh yang berbeda terhadap iklim mikro dibandingkan dengan wilayah yang mempunyai ruang hijau yang lebih banyak. Berkurangnya RTH dan makin banyaknya bangunan yang muncul mengakibatkan terjadinya kenaikan temperatur lokal dalam kota. Terjadinya kenaikan temperatur ini pada hakekatnya merupakan cerminan dari perubahan iklim mikro (Malik, 2006). Iklim mikro merupakan kondisi iklim pada suatu ruang yang sangat terbatas namun memiliki arti penting bagi kehidupan manusia, tumbuhan, dan hewan. Unsur-unsur iklim tersebut diantaranya suhu udara, kelembaban, radiasi matahari, dan curah hujan.

Kondisi RTH yang menurun seiring dengan meningkatnya kepadatan penduduk dan luas lahan terbangun di kawasan perkotaan Klaten diduga mempunyai pengaruh yang kuat terhadap iklim mikro di wilayah tersebut. Oleh sebab itu perlu dilakukan pengukuran agar dapat dianalisis perbedaan iklim mikro pada RTH yang berada pada penggunaan lahan perkotaan.

Identifikasi RTH dapat dilakukan dengan menggunakan bantuan citra penginderaan jauh beresolusi tinggi. Citra penginderaan jauh hasil proses pansharpening dapat digunakan sebagai alternatif kebutuhan citra detail, sehingga interpretabilitas secara 
visual dapat meningkat. Penggunaannya yang dikombinasikan dengan proses pansharpening untuk kajian RTH belum banyak dilakukan dan belum teruji keakuratannya. Data hasil interpretasi citra ALOS PanSharpened dapat digunakan sebagai bahan analisis dalam mencari pengaruh RTH terhadap iklim mikro di kawasan perkotaan Klaten.

Penelitian ini bertujuan sebagai berikut: (1) mengkaji manfaat dan ketelitian citra ALOS Pan-Sharpened dalam mendapatkan informasi mengenai RTH dan penggunaan lahan di kawasan perkotaan Klaten; dan (2) menganalisis pengaruh RTH terhadap iklim mikro dan kondisi iklim mikro berbagai penggunaan lahan di kawasan perkotaan Klaten.

\section{METODE PENELITIAN}

Alat dan bahan yang digunakan dalam penelitian ini diantaranya:

1. Citra ALOS AVNIR dan ALOS PRISM sebagian Kabupaten Klaten perekaman tahun 20 Juni 2009

2. Peta Rupabumi Indonesia lembar148-331 dan 148332 wilayah Klaten skala 1:25.000

1. Laptop HP core i3 RAM 4GB dan Printer Canon ip2770

2. Software ArcGIS 10.1 untuk input data, analisis, dan visualisasi data. Software ENVI 4.5 untuk pengolahan citra

3. Weathermeter untuk pengukuran suhu udara, kelembaban relatif, dan kecepatan angin, GPS (Global Positioning System) untuk cek lapangan, dan kamera digital untuk dokumentasi kegiatan

Citra ALOS Pan-Sharpened diperoleh dengan menggabungkan antara ALOS AVNIR (multispektral) dan ALOS PRISM (pankromatik). Sebelum dilakukan proses pansharpening, terlebih dahulu citra ALOS dikoreksi secara image to map menggunakan Peta RBI dan image to image dengan citra yang telah terkoreksi sebelumnya.

Informasi mengenai penggunaan lahan dan RTH di Kawasan Perkotaan Klaten diperoleh dari interpretasi visual citra ALOS Pan-Sharpened. Klasifikasi penggunaan lahan perkotaan berdasarkan klasifikasi Malingreau tingkat II, sedangkan RTH dibedakan berdasarkan kerapatan dan polanya. Uji akurasi interpretasi dan citra ALOS menggunakan metode confusion matrix.

Kerja lapangan bertujuan untuk menguji akurasi hasil interpretasi citra dan pengukuran iklim mikro. Re-interpretasi penggunaan lahan dilakukan setelah proses uji akurasi selesai. Kerja lapangan juga melakukan pengukuran terhadap suhu udara, kelembaban relatif, dan kecepatan angin sebagai parameter iklim mikro. Pengukuran dilakukan di beberapa titik sesuai sampel yang telah ditentukan. Pengukuran dilakukan menggunakan alat weathermeter pada 3 periode waktu pengukuran, yaitu pagi (06.00-07.00), siang (13.00-14.00), dan sore (16.00-17.00). Analisis dilakukan dengan 2 metode, yaitu secara statistik dan secara kualitatif deskriptif. Analisis secara statistik menggunakan teknik korelasi dan regresi sehingga didapatkan besar dan arah hubungan antar 2 variabel, sedangkan analisis secara kualitatif deskriptif dilakuakn dengan menganalisis secara spasial hubungan antara RTH dan iklim mikro.

\section{HASIL DAN PEMBAHASAN \\ Pansharpening citra ALOS}

Koreksi citra ALOS untuk keperluan pansharpening dilakukan melalui dua tahap, yaitu melakukan registrasi citra ALOS PRISM mengacu pada Peta RBI (image to map rectification)dan yang kedua registrasi citra ALOS AVNIR mengacu pada citra ALOS PRISM yang telah teregistrasi (image to image registration). Koreksi citra ALOS PRISM dilakukan terlebih dahulu karena memiliki resolusi spasial yang lebih tinggi.

Proses pansharpening citra ALOS dilakukan setelah citra mempunyai geometri dan wilayah liputan yang sama. Pada proses ini ukuran setiap piksel pada tiap saluran citra ALOS AVNIR akan disesuaikan dengan ukuran piksel dari citra ALOS PRISM, atau dengan kata lain ukuran piksel citra ALOS AVNIR (10m) diperbesar 4 kali sehingga sama dengan ukuran piksel citra ALOS PRISM (2,5m). Komposit yang digunakan adalah komposit warna asli 321. Transformasi yang digunakan dalam proses penajaman adalah transformasi Gram-Schmidt.

\section{Interpretasi Ruang Terbuka Hijau (RTH)}

RTH dapat didefinisikan sebagai liputan vegetasi di wilayah kajian, baik yang berupa vegetasi kerapatan tinggi, rendah maupun sedang. Semakin banyak pohon yang rindang pada suatu area, maka radiasi matahari tidak langsung sampai ke bumi tetapi tertahan oleh tajuk pohon sehingga suhu udara di sekitarnya menjadi menurun atau rendah yang memberikan kenyamanan kepada penduduk di lingkungan sekitarnya. Interpretasi kenampakan RTH pada citra ALOS Pansharpened dapat diinterpretasi sebagai kumpulan vegetasi yang dapat dikenali dengan beberapa kunci interpretasi dengan menggunakan komposit warna asli 321. Vegetasi dikenali dengan warna hijau hingga hijau muda hingga tua, dengan tekstur yang halus hingga kasar dan menggerombol, serta biasanya beraosisasi dengan bangunan.

Selain identifikasi sebaran RTH secara umum dari citra ALOS, kerapatan vegetasi RTH juga harus dipertimbangkan dalam menganalisis pengaruhnya 
terhadap iklim mikro. Presentase kerapatan RTH diperoleh dari hasil perbandingan antara luas liputan vegetasi dengan luas unit penggunaan lahan dikalikan $100 \%$.

Sesuai dengan Peraturan Menteri Nomor 5 tahun 2008, terdapat dua macam pola RTH yaitu mengikuti pola ekologis dan pola planologis. Namun dalam penelitian ini pola RTH yang digunakan adalah pola ekologis, yaitu pola mengelompok, memanjang, dan menyebar. Pengamatan pola RTH dilakukan secara kualitatif dari interpretasi citra ALOS.

Uji akurasi kerapatan dan pola RTH dilakukan pada sampel unit RTH yang telah ditentukan dengan metode random sampling. Uji ketelitian interpretasi dimaksudkan agar dapat diketahui seberapa besar ketelitian interpreter dalam menginterpretasi obyek pada citra yang kemudian dicocokan dengan kondisi sebenarnya dilapangan. Akurasi pembuat menjelaskan tentang ketelitian hasil interpretasi penggunaan lahan dari citra $A L O S$ terhadap kenampakan asli di lapangan, sedangkan akurasi pengguna menggambarkan ketelitian hasil interpretasi terhadap seluruh obyek yang dapat diidentifikasi pada citra ALOS.

Ketelitian citra ALOS Pan-Sharpened dalam memberikan hasil interpretasi dapat dilihat dari hasil presentase akurasi keseluruhan, untuk interpretasi kerapatan RTH sebesar 81,05\%, untuk interpretasi pola RTH sebesar 93,68\%, dan untuk interpretasi penggunaan lahan sebesar $94,97 \%$.

\section{Interpretasi Penggunaan Lahan}

Interpretasi penggunaan lahan dari citra ALOS bertujuan untuk mempermudah dalam mengindetifikasi RTH sebagai objek utama kajian dan penggunaan lahan lainnya sebagai tambahan analisis dalam kaitannya dengan iklim mikro. Interpretasi penggunaan lahan juga bertujuan untuk menyajikan data penggunaan lahan secara spasial guna memperoleh informasi mengenai persebaran heterogenitas pengunaan lahan di area kajian yang merupakan kawasan perkotaan (Gambar 1).

Tingkat akurasi keseluruhan hasil interpretasi citra adalah sebesar 94,97\%. Presentase tersebut menandakan hasil interpretasi penggunaan lahan yang telah dilakukan memiliki tingkat akurasi yang baik, sehingga hasil interpretasi citra ALOS Pan-Sharpened baik untuk memetakan penggunaan lahan di kawasan perkotaan Klaten. Secara umum, kesalahan-kesalahan interpretasi citra disebabkan oleh murni kesalahan interpreter atau memang kesalahan citra yang digunakan. Luasan masing-masing penggunaan lahan dapat dilihat pada Tabel 1.

Tabel 1. Luas penggunaan lahan

\begin{tabular}{clcc}
\hline \multicolumn{2}{c}{ Penggunaan Lahan } & Luas (Ha) & Persentase (\%) \\
\hline Daerah & Fasilitas Umum & 27,15 & 0,74 \\
Perkotaan & Industri & 64,31 & 1,76 \\
dan & Perkantoran & 114,35 & 3,14 \\
Terbangun & Pendidikan & 56,04 & 1,5 \\
& Perdagangan & 78,98 & 2,17 \\
& dan Jasa & & \\
& Permukiman & 1372,66 & 37,65 \\
& Lahan Non & 1716,37 & 47,07 \\
& Terbangun- & & \\
& Sawah & & \\
& Lahan Non & 36,77 & 1,01 \\
& Terbangun- & & \\
& Kebun & & \\
& Campuran & & 4,96 \\
& Jalan & 181,04 & 100 \\
\hline & Total & 3647,67 &
\end{tabular}

Sumber: Pengolahan Data

\section{Kondisi Iklim Mikro Daerah Penelitian}

Iklim mikro menggambarkan kondisi iklim dalam wilayah yang terbatas dan berpengaruh langsung terhadap aktivitas manusia di dalamnya, namun memiliki arti penting bagi kehidupan manusia, tumbuhan, dan hewan. Pengukuran suhu udara, kelembaban relatif, dan kecepatan angin dilakukan dalam waktu sehari untuk mendapatkan data iklim mikro yang seragam.

Pengukuran suhu udara, kelembaban udara, dan kecepatan angin dilakukan pada 91 titik sampel dengan memperhitungkan kerapatan dan pola RTH. Berdasarkan hasil pengukuran didapatkan suhu rerata harian terendah adalah $28,12^{\circ} \mathrm{C}$ dan tertinggi $31,19^{\circ} \mathrm{C}$ dengan rata-rata suhu sebesar $30,11^{\circ} \mathrm{C}$.

Kelembaban relatif rerata harian terendah adalah $61,13 \%$ dan tertinggi $75,17 \%$ dengan rata-rata kelembaban relatif sebesar $68,74 \%$. Kcepatan angin rerata harian terendah adalah $0,22 \mathrm{~m} / \mathrm{s}$ dan tertinggi $1,19 \mathrm{~m} / \mathrm{s}$ dengan rata-rata kecepatan angin sebesar 0,62 $\mathrm{m} / \mathrm{s}$. Peta suhu, kelembaban, dan angin Kawasan Perkotaan Klaten dapat dilihat pada Gambar 2, 3, dan 4. 


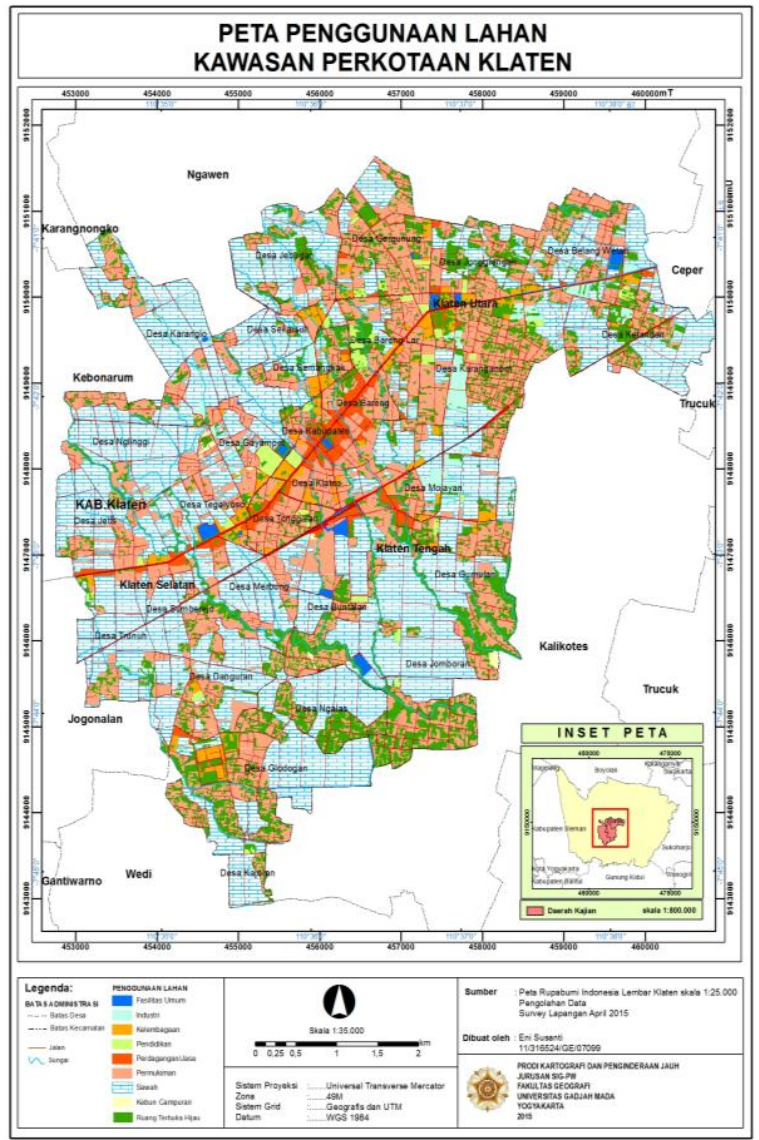

Gambar 1. Peta Penggunaan Lahan Kawasan Perkotaan Klaten

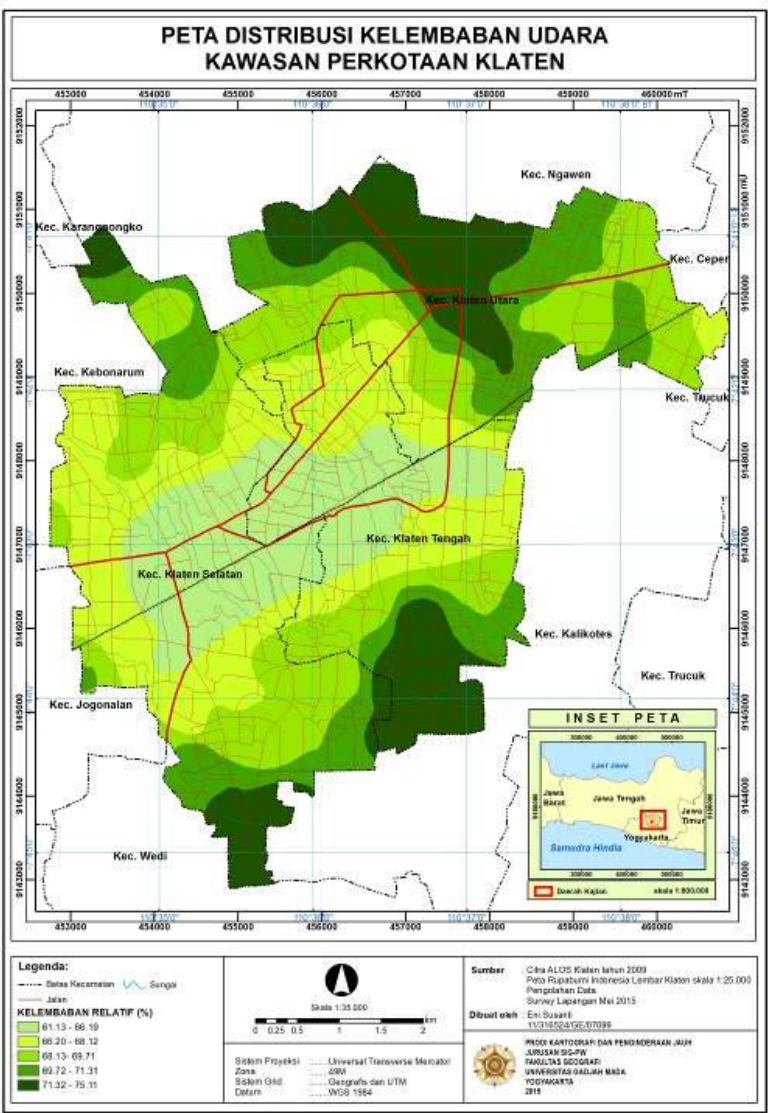

Gambar 3. Peta Distribusi Kelembaban Udara Kawasan Perkotaan Klaten

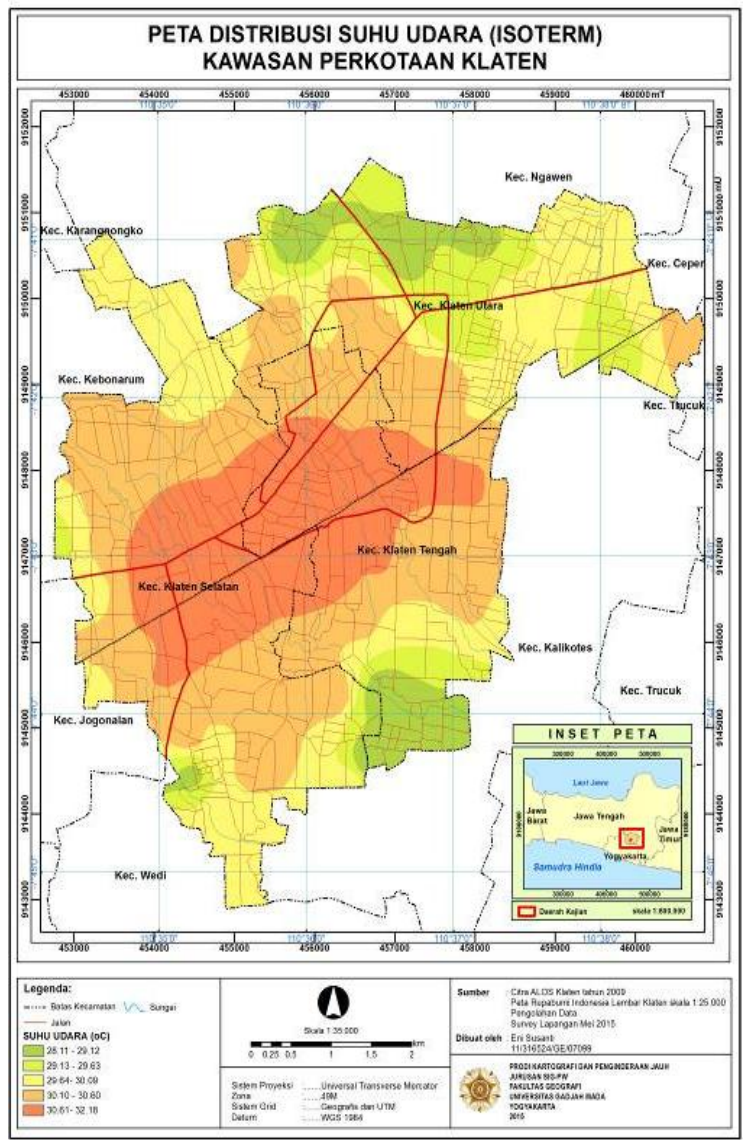

Gambar 2. Peta Distribusi Suhu Udara Kawasan Perkotaan Klaten

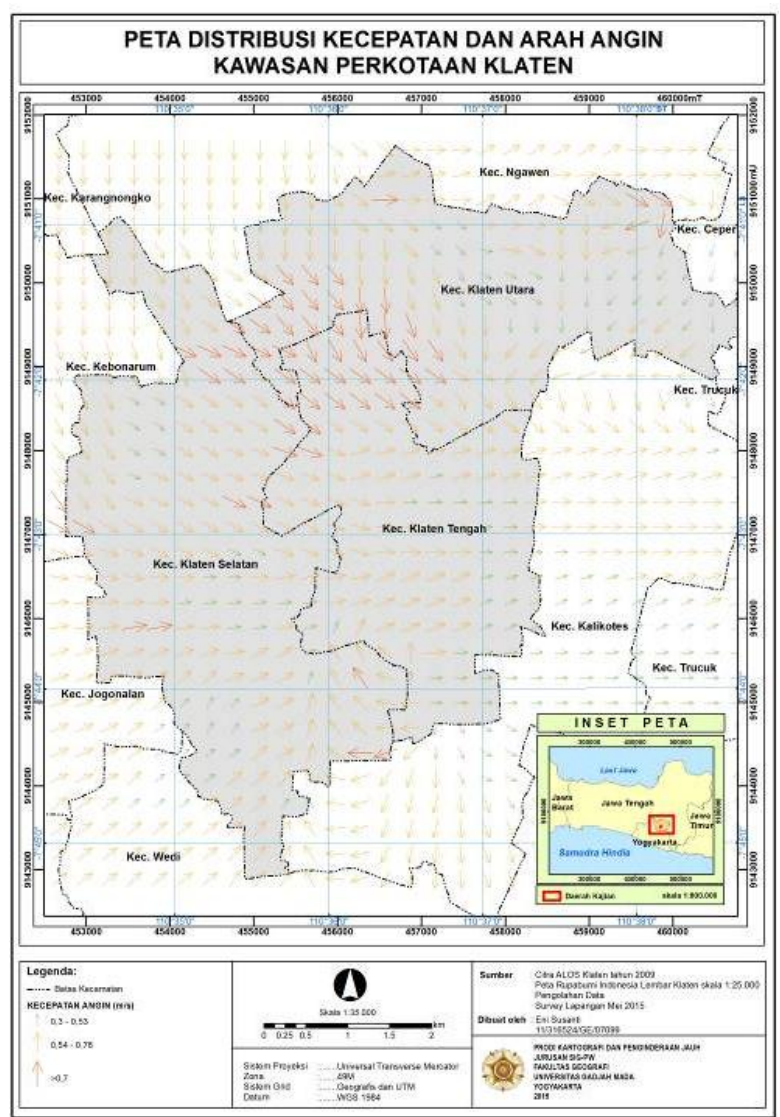

Gambar 4. Peta Angin Kawasan Perkotaan Klaten 


\section{Analisis Pengaruh Kerapatan RTH terhadap Iklim Mikro}

Hasil pengukuran suhu udara, kelembaban relatif, dan kecepatan angin pada RTH bertujuan untuk melihat ada atau tidaknya pengaruh kerapatan RTH terhadap iklim mikro, jika ada berapa besarnya dan bagaimana arah hubungannya. Berdasarkan hasil analisis statistik korelasi diperoleh faktor iklim mikro yang mempunyai hubungan dengan kerapatan RTH adalah suhu udara, kelembaban udara, dan kecepatan angin dengan nilai signifikansi pada ketiga periode pengukuran (pagi, siang, dan sore) serta rerata suhu mempunyai nilai signifikansi $<0,05$. Hal ini membuktikan bahwa perbedaan karakteristik kerapatan RTH dapat berpengaruh terhadap tinggi rendahnya nilai suhu udara, kelembaban relatif, dan kecepatan angin. Koefisien korelasi antara suhu udara adalah bernilai negatif (-) yang berarti adanya hubungan berkebalikan antara keduanya, dimana semakin tinggi kerapatan RTH maka semakin rendah suhu udara. Sedangkan koefisien korelasi kelembaban udara dengan kerapatan RTH bernilai positif $(+)$ yang berarti keduanya mempunyai hubungan searah, dimana semakin tinggi kerapatan RTH di suatu area maka semakin tinggi pula kelembaban udara di area tersebut. Koefisien korelasi antara kerapatan RTH dengan kecepatan angin juga mempunyai nilai negatif (-) yang berarti adanya hubungan berkebalikan antara keduanya, dimana semakin tinggi kerapatan RTH maka semakin rendah kecepatan angin, sehingga berdasarkan data tersebut dapat dinyatakan bahwa RTH memiliki karakteristik vegetasi yang mampu dengan efektif mereduksi suhu udara, kecepatan angin dan meningkatkan kelembaban udara. Anomali terjadi pada nilai signifikansi kecepatan angin sore hari yang mempunyai nilai 0,727 atau $>0,05$ yang menunjukkan tidak adanya hubungan.

Analisis regresi linier sederhana antara kerapatan RTH dengan suhu udara rerata harian didapatkan persamaan regresi $y=31,612-0,399 x$ dan $R^{2}=0,606$. Hal ini berarti setiap kenaikan 1 tingkat kerapatan $\mathrm{RTH}$ mempengaruhi suhu udara sebesar $31,213^{\circ} \mathrm{C}$, kerapatan RTH tingkat 2 mempengaruhi suhu udara sebesar $30,814^{\circ} \mathrm{C}$, dan seterusnya. Koefisien regresi yang dinyatakan dengan nilai $\mathrm{R}^{2}$ sebesar 0,606 menunjukkan hubungan antar kedua variabel adalah kuat yang berarti kerapatan RTH mempengaruhi suhu udara sebesar $60,6 \%$, sedangkan $39,4 \%$ sisanya adalah faktor lain yang dapat mempengaruhi suhu udara di area penelitian.

Analisis regresi linier sederhana antara kerapatan RTH dengan kelembaban udara rerata harian didapatkan persamaan regresi $y=61,724+2,729 x$ dan
$\mathrm{R}^{2}=0$,8. Hal ini berarti setiap kenaikan 1 tingkat kerapatan RTH mempengaruhi kelembaban udara sebesar 64,45\%, kerapatan RTH tingkat 2 mempengaruhi kelembaban udara sebesar $67,18 \%$, dan seterusnya. Koefisien regresi yang dinyatakan dengan nilai $\mathrm{R}^{2}$ sebesar 0,8 menunjukkan tingkat hubungan yang sangat kuat antara kerapatan RTH dengan kelembaban udara yang berarti kerapatan RTH mempengaruhi kelembaban udara sebesar 80\%, sedangkan $20 \%$ sisanya adalah faktor lain yang dapat mempengaruhi kelembaban udara di area penelitian.

Hasil dari regresi linier antara kerapatan RTH dan kecepatan angin menunjukkan nilai $\mathrm{R}^{2}=0,052$ dengan persamaan regresi $y=0,732-0,43 x$. Nilai $R^{2}$ menunjukkan bahwa kecepatan angin dipengaruhi oleh kerapatan RTH sebesar 5,2\%. Nilai yang termasuk kecil dan bahkan sifat hubungannya adalah lemah. Pertambahan tingkat kerapatan RTH diiringi perubahan kecepatan angin namun dengan nilai yang fluktuatif.

\section{Analisis Pengaruh Pola RTH terhadap Iklim Mikro}

Hasil pengukuran suhu udara, kelembaban relatif, dan kecepatan angin pada RTH bertujuan untuk melihat ada atau tidaknya pengaruh pola RTH terhadap iklim mikro, jika ada berapa besarnya dan bagaimana arah hubungannya. Analisis dilakukan dengan menggunakan dua metode yaitu secara statistik dan yang kedua secara kualitiatif deskriptif. Analisis statitik yang pertama menggunakan analisis korelasi koefisien kontingensi. Berdasarkan hasil yang diperoleh, faktor iklim mikro yang mempunyai hubungan yang lemah bahkan tidak berhubungan dengan pola RTH. Hal ini dibuktikan dengan nilai signifikan pada ke ketiga pola RTH yang bernilai $>0,05$ yang berarti H0 diterima. Pola RTH dengan suhu udara memiliki nilai signifikansi 0,06; dengan kelembaban udara sebesar 0,76;serta dengan kecepatan angin sebesar 0,263. Berdasarkan data tersebut dapat dinyatakan bahwa pola RTH tidak mempengaruhi iklim mikro secara signifikan. Terdapat faktor lain yang lebih mendominasi terhadap iklim mikro yaitu kerapatan RTH.

Rerata suhu harian pola RTH mengelompok adalah $29,31^{\circ} \mathrm{C}$; RTH pola menyebar mempunyai rerata suhu udara harian sebesar $28,20^{\circ} \mathrm{C}$; RTH pola memanjang mempunyai rerata suhu udara harian sebesar $28,36^{\circ} \mathrm{C}$; dan lokasi yang tidak bervegetasi mempunyai rerata suhu udara harian sebesar $31,02^{\circ} \mathrm{C}$. Rerata kelembaban udara harian pola RTH mengelompok adalah $71,53 \%$; RTH pola menyebar mempunyai rerata kelembaban udara harian sebesar 69,31\%; RTH pola memanjang mempunyai rerata kelembaban udara harian sebesar $67,05 \%$; dan lokasi yang tidak bervegetasi mempunyai 
rerata kelembaban udara harian sebesar 65,85\%. Kecepatan angin pada pola RTH mengelompok paling rendah dibandingkan dengan pola yang lain yaitu ratarata kecepatan angin harian berkisar $0,57 \mathrm{~m} / \mathrm{s}$.

\section{Pengaruh Penggunaan Lahan terhadap Iklim Mikro}

Hubungan iklim mikro pada berbagai penggunaan lahan dapat dianalisis secara statistik. Berdasarkan analisis korelasi yang dilakukan didapatkan nilai signifikansi sebesar 0 untuk korelasi rerata suhu harian dengan penggunaan lahan, nilai signifikansi sebesar 0 untuk korelasi rerata kelembaban udara harian dengan penggunaan lahan, dan nilai signifikansi sebesar 0 untuk korelasi rerata kelembaban udara harian dengan penggunaan lahan.

Berdasarkan hasil yang didapat disimpulkan bahwa variabel iklim mikro yang mempunyai korelasi/hubungan dengan penggunaan lahan adalah kelembaban udara, suhu udara dan kecepatan angin. Hal ini membuktikan bahwa setiap penggunaan lahan memiliki kemampuan yang berbeda dalam meningkatkan kelembaban udara, suhu udara dan kecepatan angin.

Suhu udara tertinggi berada di penggunaaan lahan fasilitas umum disusul dengan jalan dan kemudian lahan non terbangun berupa lahan sawah. Beberapa sampel fasilitas umum sampel terminal bus, stasiun, GOR, dan rumah sakit. Di keempat lokasi tersebut banyak terjadi polusi dan peningkatan emisi gas kendaraan bermotor. Emisi dan polusi tanpa diimbangi dengan keberadaan RTH dapat meningkatkan suhu udara dan menurunkan kelembaban udara. Suhu rerata harian terendah dimiliki oleh kawasan permukiman. Kawasan permukiman di Kawasan Perkotaan Klaten sebagian besar berasosiasi dengan keberadaan RTH, seperti pada permukiman di desa Glodogan dan Desa Jomboran. Selain jauh dari pusat kota sehingga minim dengan polusi dan emisi gas kendaraan bermotor, di kedua desa tersebut memiliki kerapatan RTH yang tinggi, sehingga fungsi RTH dapat berjalan dengan maksimal.

Kecepatan angin pada berbagai penggunaan lahan mempunyai hubungan $\mathrm{R}^{2}=0,143$ yang berarti penggunaan lahan dapat mempengaruhi kecepatan angin sebesar $14,3 \%$. Namun hubungan antara kedua variabel sangat lemah yang juga mengindikasikan penggunaan lahan tidak berpengaruh secara signifikan terhadap kecepatan angin. Kecepatan angin tertinggi dimiliki oleh kawasan perdagangan dan jasa pada tiga periode waktu serta rerata kecepatan anginnya. Kawasan perdagangan jasa sebagian besar terletak di tepi jalan besar dengan intensitas kendaraan yang lewat sangat tinggi. Kendaraan yang melaju mempercepat aliran udara di sekitarnya sehingga timbulah angin lokal di area tersebut. Semakin banyak kendaraan yang melaju semakin tinggi pula potensi udara mengalir lebih cepat di area tersebut.

Kawasan lahan non terbangun mempunyai kecepatan angin tertinggi kedua setelah kawasan perdagangan dan jasa. Angin dapat melaju lebih kencang pada area yang tidak mempunyai material padat di atasnya, seperti bangunan maupun pepohonan. Jika suatu area memiliki dua hal tersebut, angin yang datang akan terpecah memnajdi beberapa bagian yang akibatnya angin akan melambat kecepatannya. Kepadatan bangunan yang tinggi akan memicu terjadinya turbulensi angin yang menyebabkan angin berputar-putar di sekitar bangunan tersebut. Berbeda halnya dengan kawasan lahan non terbangun semisal area persawahan. Di area tersebut angin yang datang tidak akan terpecah sehingga kecepatan angin akan konstan sesuai dengan kecepatan awal. Berdasarkan kondisi tersebut maka terbukti pada penelitian ini bahwa kecepatan angin di kawasan lahan non terbangun dengan sampel area perswahan memiliki kecepatan angin yang tergolong tinggi dibandingkan dengan penggunaan lahan lainnya.

\section{KESIMPULAN}

1. Citra ALOS Pan-Sharpened bermanfaat dalam menyadap informasi mengenai RTH dan penggunaan lahan dengan resolusi yang tinggi hasil dari proses pansharpening sehingga mempermudah interpreter dalam mengidentifikasi obyek. Resolusi spasial yang tinggi ini menghasilkan tingkat ketelitian yang tinggi pula. Ketelitian citra ALOS Pan-Sharpened dalam memberikan hasil interpretasi dapat dilihat dari hasil presentasenya, untuk interpretasi kerapatan RTH sebesar 81,05\%, untuk interpretasi pola RTH sebesar $93,68 \%$, dan untuk interpretasi penggunaan lahan sebesar 94,97\%.

2. Kerapatan vegetasi Ruang Terbuka Hijau memberikan pengaruh yang signifikan terhadap iklim mikro, untuk pengaruhnya terhadap suhu udara adalah $60,6 \%$, pengaruhnya terhadap kelembaban udara adalah $80 \%$, dan pengaruhnya terhadap kecepatan angin adalah 5,2\%. Pola vegetasi RTH kurang memberikan pengaruh yang signifikan terhadap iklim mikro yang ditandai dengan korelasi yang sangat lemah antara berbagai pola vegetasi RTH dengan suhu udara, kelembaban udara, dan kecepatan angin. Pengaruh penggunaan lahan terhadap iklim mikro adalah rendah, dimana suhu udara, kelembaban udara, dan kecepatan angin lebih dipengaruhi oleh tingkat kepadatan bangunan, geometri bangunan, tingkat emisivitas 
bangunan, emisi gas kendaraan bermotor, dan ketersediaan RTH.

\section{DAFTAR PUSTAKA}

Arsyad, S. (1989). Konservasi Tanah dan Air. Bogor. IPB Press.

Budiyanto, E. (2007). Aplikasi Penginderaan Jauh untuk Usulan Penataan Ruang Terbuka Hijau daerah Permukiman di sebagian Kota Yogyakarta. Skripsi. Yogyakarta. Fakultas Geografi UGM.

Direktorat Jenderal Penataan Ruang. (2008). PEDOMAN - Penyediaan Dan Pemanfaatan Ruang Terbuka Hijau Di Kawasan Perkotaan. Jakarta. Departemen Pekerjaan Umum.

Instruksi Menteri dalam Negeri No. 14 tahun 1988 tentang Penataan Ruang terbuka Hijau di Wilayah Perkotaan.

Malingreau, J.P., dan Rosalina Cristiani. (1982). A Lend Cover/Land Use Classification for Indonesia First Revision. Yogyakarta. Puspic Universitas Gadjah Mada
Peraturan Menteri Pekerjaan Umum No. 5 tahun 2008 tentang Pedoman Penyediaan dan Pemanfaatan Ruang Terbuka Hijau di Kawasan Perkotaan.

Sitanggang, G. (2008). Teknik dan Metode Fusi (Pansharpening) Data ALOS (AVNIR-2 dan PRISM) untuk Identifikasi Penutup Lahan/Tanaman Pertanian Sawah. Majalah Sains dan Teknologi Dirgantara. 3(1), 33-49.

Suharyadi. (2001). Penginderaan Jauh untuk Studi Kota. Yogyakarta. Fakultas Geografi Universitas Gadjah Mada.

Sutanto. (1986). Penginderaan Jauh untuk Penggunaan Lahan. PUSPIC UGM - BAKOSURTANAL. Yogyakarta. Universitas Gadjah Mada.

Sutanto. (1999). Penginderaan Jauh Jilid 1. Yogyakarta. Gadjah Mada University Press.

Tjasyono, B. (2004). Klimatologi. Bandung. Institut Teknologi Bandung.

Undang-Undang Republik Indonesia Nomor 26 tahun 2007 tentang Penataan Ruang. 